\title{
27 Exploring the possibility of a meat tax
}

\author{
Floris de Graad
}

Significant changes start small. With a new starting point. Paying the actual price of a product is such a starting point. It can lead to change on all levels. In this case we explore the effects of paying the actual price of meat.

The significant challenges of our era come together in our meat consumption. It's like a magnifying glass that projects the issues at the focal point on our plates. But because we all eat every day, this is also the field in which we're not powerless. We are all part of it. And the hopeful thing is: if we can create changes regarding this complicated issue, it can be done for many other areas, too.

Of course, good intentions and conscious consumption are commendable. But it won't be enough. To paraphrase Adam Smith's famous words, an invisible hand is intervening. Also as long as this invisible hand intervenes root causes of today's food-related problems can only poorly be addressed. This invisible hand consists of the principle that many of the costs related to the production and consumption of meat are not included in the price. Food products from systems that cause the most damage appear to be the most affordable, while more sustainably produced food seems expensive. Biojournaal (2018), Benveniste (2018), Schravesande (2009). In short, we do not pay the actual price for meat.

To be sustainable, all social costs which come with the production and consumption of meat should be included in the price. Although these costs are still invisible in most cases today, they're no less real because of that. Sooner or later, they have to be paid by someone. Choosing for a realistic price - in this case of meat - is a matter of moral consciousness. It's not about left or right. It is just that consumers can't organise this themselves. But it can be done with the introduction of a meat tax.

This meat tax should at least cover the social costs of production and consumption of meat. Think about deforestation, climate change, soil erosion, antibiotic resistance, water consumption, ammonia emissions, health, among others. Social costs are being made and left unpaid for in all these areas.

\section{The problem}

The demand for food is ever increasing. World population is projected to grow to 9 billion people by 2050 . To meet the growing demand, the 
United Nations Convention to Combat Desertification expects global food production would need to increase by $50 \%$. Others, like the FAO project a $60 \%$ increase or even a doubling.

Apart from the growing population, the demand for animal protein is increasing due to changing consumption patterns. Booming economies like China are increasing their consumption of meat while diary is becoming more popular in India. In general, these countries follow the same route Western Europe did half a century ago.

On the other hand, a reverse transition away from animal products is about to breakthrough in Europe and the United States. This reverse transition is an important trend, since animal protein has disproportionate environmental impacts, particularly, when produced in intensive production systems employing massive use of feed crops.

For food sustainability, climate change is often considered paramount. However, about a dozen of the most critical issues were listed by Rockström et al. (2009), who identified and quantified several boundary values that should not be transgressed. Subsequently, these were ranked by Aiking $(2014,2018)$, showing that food production is an essential driver of all of them, without exception. The rate of biodiversity loss, the nitrogen cycle disruption and climate change did already cross the boundary of non-reversible impact, with biodiversity loss being most dramatic.

The production of animal proteins (meat, dairy and eggs) is, in many cases highly inefficient. Animals need to be fed to 'produce' proteins. Conversion losses from plant to animal protein by livestock are $85 \%$ on average (both nitrogen and energy). As a consequence, $77 \%$ of all agricultural land is dedicated to livestock and livestock feed production.

This land claim means a big share of the problems associated with food production, in general, has, after all, to be assigned to the production of animal proteins.

Poore and Nemecek (2018) claim moving from current diets to a diet that excludes animal products has transformative potential, reducing food's land use by 3.1 (2.8 to 3.3 ) billion ha (a $76 \%$ reduction), including a 19\% reduction in arable land. Food's greenhouse gas emissions would be reduced by 6.6 (5.5 to 7.4) billion metric tons of $\mathrm{CO}_{2}$ eq (a $49 \%$ reduction).

The transformative potential of a diet without animal products also include acidification by 50\% (45 to 54\%); eutrophication by $49 \%$ (37 to $56 \%$ ); and scarcity-weighted freshwater withdrawals by $19 \%$ (-5 to $32 \%)$ for a 2010 reference year.

In short: an area as large as Africa could be withdrawn from agriculture when the world would shift to a plant-based diet. However, the optimum from the land use-perspective is probably a diet with little use of dairy, since some pasture lands can only be used for livestock, while grazing on pasture lands is possible with little harm to environment and biodiversity.

But for now, over the past 50 years, increased demand for animal products has accounted for $65 \%$ of agricultural land-use change. 
Meanwhile, the conditions for increased food production are worsening, mainly due to land degradation. The causes of land degradation are many and often intertwined with the problems mentioned above, but land degradation poses a problem in its own right. Land degradation is the most severe threat to food production, food security, and natural resource conservation in Africa, particularly for the poor and vulnerable population of the drylands. About $73 \%$ of the African drylands are degraded, and 51\% are severely degraded. At least 485 million Africans are affected by land degradation which is a widespread problem that affects soils, landscapes, and human welfare (Bado \& Bationo 2018). Some scholars call land degradation even 'the single most pressing current global problem'. However, reliable data on land degradation is still scarce.

Furthermore, intensive animal protein production requires 10-1000 times more water than plant protein.

Antibiotic resistance is becoming an increasingly severe threat to human health through the progressive loss of effective therapeutic treatment options for many diseases and infections. While a large part of this problem stems from over-use of antibiotics in medical care, another part comes from their use in agriculture. Apart from costs related to the production of animal proteins, there are also many costs associated with the consumption of (mainly red) meat:

The consumption of red and processed meat exceeds recommended levels in most high and middle-income countries and has been associated with a range of adverse health impacts. In 2015, the cancer agency of the World Health Organization, the International Agency for Research on Cancer (IARC), classified the consumption of red meat, which includes beef, lamb, and pork, as carcinogenic to humans if eaten in processed form, and as probably carcinogenic if eaten unprocessed. In addition to being linked with cancer, the consumption of red and processed meat has also been associated with increased rates of coronary heart disease, stroke, type 2 diabetes mellitus and overall mortality.

(Springmann et al. 2018)

According to Springmann et al., the consumption of red meat was associated with 860,000 deaths globally in the year 2020, and that of processed meat with $1,530,000$ deaths. When assessed together, those represented $4.4 \%$ of all projected deaths in the analysis in that year.

About two-thirds of attributable deaths (64\%) occurred in middle-income countries, one third (32\%) in high-income countries, and a small portion (4\%) in low-income countries: 'Those impacts and the IARC's classification raise the question whether the consumption of red and processed meat should be regulated similar to other carcinogens or to other foods of public health concern, such as sugary drinks' (Springmann et al. 2018). Much of the cost that comes with the above has already been calculated; some subjects need further research. But they have never been added up. 


\section{What can be calculated and monetised}

It sounds unusual; we are buying something of which we don't know the price. However, everything points to the price being high. Research into the actual cost of meat is therefore necessary. The good news is that modern techniques and extensive mathematical models make it easier to calculate the actual price. Due to health regulations the food chain is becoming more and more transparent. In the EU for example, meat companies are obligated to trace down and give insight into the origins of their meat within four hours after request. With an identification number for GlobalGAP number (a farm assurance programme, guaranteeing good agricultural practice) printed on labelled food, a registration system is already in place that can be used to trace down to the farm level.

Anyone who thinks of the principle of a real price as flights of fancy does not take into account that large companies, insurers and consultancy firms have been working to calculate the financial consequences of applying a real price to their industry for some years now. These calculations are made only because they expect that society will desire the use of an actual cost in the near future. A leading think tank of investors from the banking and insurance world expects the time for the introduction of a meat tax to be ready within five years.

No academic studies have yet attempted to estimate the total costs of agricultural externalities throughout the European Union as a whole, but the campaign organisation Compassion in World Farming (2016) estimated total negative externalities of agriculture in the EU to be just under $€ 170$ billion per year. Still this estimate appears incomplete since not from all countries necessary data was available.

It is clear, however, that the hidden costs of nitrogen compounds release alone already outweighs the profits made in the continent's agricultural sector. Intensive livestock production releases nitrogen compounds such as ammonia into the atmosphere, contributing markedly to climate change. According to the European Nitrogen Assessment in 2011, this damage amounted to some 70 to 320 billion dollars in Europe. The study concluded that this sum could exceed all the profits made in the agricultural sector.

For the UK, The Sustainable Food Trust calculated the total hidden costs of food $f_{12} 120.14$ billion. Not all costs in this study can be solely related to animal protein (like the costs of unhealthy diets in general), but the breakdown of some costs is still instructive. The hidden water-related costs are estimated at around $\mathcal{f}_{1.49}$ billion, including water pollution and flooding due to poor soil maintenance. The report also cites a study by Eswaran, Hall and Reich, in which it is estimated that the cost of worldwide soil degradation have increased from $\$ 400$ billion per year ( $\$ 70$ per person per year) to between $\$ 6.3$ trillion and $\$ 10.6$ trillion annually. This estimate includes erosion, degradation, and the loss of ecosystem services. It is worrying that the United Nations Convention to Combat Desertification estimated this year the annual costs of land degradation range between $\$ 18$ billion and a 20 trillion. 
Table 27.1 The 'real' price of meat for the Netherlands

\begin{tabular}{lcrl}
\hline & Pork & \multicolumn{1}{l}{ Beef } & Chicken \\
\hline Retail price & $€ 7.75$ & $€ 12.17$ & $€ 7.00$ \\
Climate damage & $€ 1.06$ & $€ 1.29$ & $€ 0.62$ \\
Environmental damage & $€ 2.81$ & $€ 2.73$ & $€ 1.10$ \\
Land use (biodiversity) & $€ 0.09$ & $€ 0.12$ & $€ 0.05$ \\
subsidies & $€ 0.02$ & $€ 0.42$ & $€ 0.01$ \\
Animal diseases & $€ 0.10$ & $€ 0.53$ & $€ 0.03$ \\
'external benefits' & $€ 0.00$ & $-€ 0.20$ & $€ 0.00$ \\
'Real price' & $€ 11.83$ & $€ 17.06$ & $€ 8.80$ \\
Additional costs as percentage of retail price & $53 \%$ & $40 \%$ & $26 \%$ \\
\hline
\end{tabular}

Source: CE Delft, de echte prijs van vlees.

Climate change is maybe the hardest aspect to calculate. Valuing a tonne of carbon based on the full social impact on human society and the environment is a complex task and estimates for the social cost of carbon range widely, from $\$ 21$ to $\$ 900$ per tonne. Also, the impact loses (and benefits) of climate change seem hard to predict and can mostly only be determined afterwards.

One of the most accurate studies into the 'real' price of meat has been carried out in the Netherlands by CE Delft. CE Delft calculated the 'real' price of meat for the Netherlands (Table 27.1).

As CE Delft indicates in the report, conservative estimates are used to define the costs, and liberal estimates are used to define the external profits (additional profits, actually not calculated in the retail price). CE Delft created a manual for pricing environmental costs (Handboek Milieuprijzen) with indicative prices for a wide range of environmental costs, both for production in the Netherlands as the EU as a whole. The study finds that retail prices would increase significantly when a real price is adapted for pork $(+53 \%)$, beef $(+40 \%)$ and chicken (+26\%). Though this study seems quite elaborate, it does not yet cover health-related costs.

In the UK, around $45 \%$ of antibiotics are used for animals, and in the EU as a whole, the figure is about $66 \%$. Antibiotic resistance is becoming an increasingly severe threat to human health through the progressive loss of effective therapeutic treatment options for many diseases and infections. While a large part of this problem stems from the over-use of antibiotics in medical care, another part comes from their use in agriculture. Many of these are not used to treat sick animals but are added to feed and water used for preventative purposes. Livestock is increasingly developing drug-resistant bacteria in their intestines and sometimes on their skin that can remain on meat and pass to humans. The Sustainable Food Trust report cites a UK study on the economic burden of antimicrobial resistance, indicating that the cost to society could be as high as $£ 10$ billion per year.

On the consumption side, also estimates of hidden health-related costs circulate. Springmann et al. (2018) attribute $\$ 285$ billion to the consumption 


\section{Floris de Graad}

of red and processed red meat worldwide, three-quarters of which were due to processed meat consumption. According to Koorenman (2013) a rough calculation shows that the annual costs in the Netherlands for the curative treatment of cardiovascular diseases alone amounts at around 7 billion euros.

\section{Taxation}

Interestingly, both Springmann et al. and Koorenman estimate the effect of taxation. Koorenman (2013) suggests raising taxation for meat to a level effectively halving the consumption of meat. The $€ 7$ billion associated with the curative treatment of cardiovascular diseases would fall by $€ 1$ billion. The assumption is that a halving of meat consumption leads to a decrease in health care costs for cardiovascular diseases by $16 \%$. This numbers relate to that part of the population that is currently not a vegetarian (around 95\%). Besides the costs of treating cancer, diabetes, cancer and arthrosis will fall.

The extra tax revenue would be around three billion euros. Current spending on meat in the Netherlands is approximately six billion euros a year. With a doubling of the retail price and halving of the consumption, total spending will remain the same, with half of the amount being tax revenues. This can be used for low-income compensations masseurs, the promotion of sustainable agriculture and the compensation for job losses in the meat sector.

Springmann et al. (2018) describe an 'optimal taxation', which prevents the danger of malnutrition in low-income countries due to higher meat prices. He forecasts that under 'optimal taxation', prices for processed meat will on average increase by $25 \%$. (ranging from $1 \%$ in low-income countries to over $100 \%$ in high-income countries). Prices for red meat will increase by $4 \%$, ranging from $0.2 \%$ to over $20 \%$.

This will lead to a fall of consumption by $16 \%$ on average, ranging from $1 \%$ to $25 \%$, while red meat consumption remained stable as substitution for processed meat.

As a result, the number of deaths attributable to red and processed meat consumption decreased by 9 and attributable health costs decreased by $14 \%$ ( $\$ 41$ billion) globally. In both cases the highest reduction is to be foreseen in high and middle-income countries.

In the Netherlands, the True Animal Protein Price Coalition and the Dutch Vegetarian Society asked CE Delft to calculate the possibilities and impact of a meat tax. This report (Vergeer et al. 2019) builds upon the report mentioned above (and therefore does not include hidden health costs) and will be released in September 2019. Based on the concept, CE Delft concludes the introduction of a meat tax will be feasible within two years when adopted in phases and reaching full implementation and impact by 2030. By this year per $\mathrm{kg}$ meat, the consumer price will be raised with $€ 5.70$ for beef, $€ 4.50$ for pork and $€ 2.04$ for chicken. 
The most simple methodology suggested in the report levies taxes at the point of selling (retailers and butcher's shops), based on the kind and weight of the meat purchased. This will stimulate producers to use less meat in their products. As a result, meat consumption is expected to fall by $50 \%$ when fully implemented. The monetised positive impact amounts of 1.5 billion euros. Tax revenues will be 2390 billion euros annually.

A more comprehensive variant includes an emission registration system (fine dust, $\mathrm{NH}_{3}, \mathrm{NOx}$, greenhouse gasses) for farmers, which will allow for immediate reflection in the tax level at the point of sale. The benefit of this variant is the incentive for farmers to implement sustainability measures and innovations. The impact on consumer behaviour is expected to be the same in both variants.

The suggested taxation systems do also cover imported meat, whilst meat production destined for export is excluded. This way, legally no obstacles are to be expected, since no producer category either national or abroad, is favoured or disfavoured by the system. Apart from VAT taxes, which are defined by basis and limited by scope, EU member states are free to levy new kinds of taxes.

The report corrects the environmental impact of the tax on changing consumer patterns. Consumers will substitute meat by other products, like cheese or meat-replacers, also harming the environment.

\section{Conclusion}

Naturally, the income from a meat tax must be spent on measures that mitigate or compensate for the impact of meat production and consumption. How this happens will always depend to a large extent on the political leanings of the government. But in this context, measures are also conceivable that compensate the initial loss of purchasing power through the meat tax. CE Delft proposes to return half of the tax revenues to taxpayers, so in the end a majority of taxpayers benefit. This kind of measures can make a meat tax more acceptable to politics but are not part of the ethics of a true price as such.

In a later phase, it would be logic to broaden the scope of a meat tax to a tax on animal proteins in general. Many of the mentioned negative aspects of meat also apply to milk and eggs. For the beginning, however, it seems recommendable to start with a meat tax.

\section{Abbreviations}

$\mathrm{CO}_{2}$ eq carbon dioxide equivalent

FAO Food and Agricultural Organization of the United Nations

IARC International Agency for Research on Cancer, the cancer agency of the World Health Organization

$\mathrm{NH}_{3}$ ammonia

$\mathrm{NOx}$ nitric oxide 


\section{Floris de Graad}

\section{References}

Aiking, H. (2014). Protein Production: Planet, Profit, Plus People? The American Journal of Clinical Nutrition 100(suppl. 1), 483S-489S.

Aiking, H. (2018). The Next Protein Transition. Amsterdam: Netherlands Institute for Environmental Studies, VU University.

Bado, V. and Bationo, A. (2018). Advances in Agronomy 150, 1-33.

Benveniste, A. (2018). Average Americans Can't Afford to buy Green. Retrieved from www. bloomberg.com/news/articles/2019-03-07/it-s-not-cheap-being-a-green-consumer.

Biojournaal (2018). Waarom is biologische voiding duur(der)? Retrieved from https:// allesoverbio.be/artikels/waarom-is-biologische-voeding-duur-der.

Compassion in World Farming (2016). Cheap Food Costs Dear. Godalming: Compassion in World Farming. Retrieved from http://tinyurl.com/zpy3y8t.

Koorenman, P. (2013). Belastend vlees en vleesbelasting. ESB Economisch Statische Berichten, jaargang 98, 19 April.

Poore, J. and Nemecek, T. (2018). Reducing Food's Environmental Impacts through Producers and Consumers. Science 360, 987-992.

Rockström, J. et al., (2009). A Safe Operating Space for Humanity. Nature 461, 472-475.

Schravesande, F. (2009). Biologisch voedsel is zo duur, maar hoe komt dat? Retrieved from www.nrc.nl/nieuws/2009/09/16/biologisch-voedsel-is-zo-duur-maar-hoe-komtdat-11782972-a457899.

Springmann, M., Mason-D’Croz, D., Robinson, S., Wiebe K., Godfray, H. C. J., et al., (2018). Health-Motivated Taxes on Red and Processed Meat: A Modelling Study on Optimal Tax Levels and Associated Health Impacts. PLOS ONE 13(11). Retrieved from https://doi.org/10.1371/journal.pone.0204139.

Vergeer, R. et al., (2019). Duurzaamheidsbijdrage vlees. Delft: CE Delft. 